\title{
Abundance and Size Distribution of Particulate Matter Fractions Near a Caribbean Bank Barrier Reef
}

\author{
G. M. Simmons, Jr. \\ Virginia Polytechnic Institute and State University, Department of Biology, Blacksburg, Virginia 24061, USA
}

\begin{abstract}
Recent research indicates that corals have the ability to occupy several trophic levels and that particulate matter (PM) appears to play a major role in meeting their daily energy requirements. A study was undertaken to determine the amount and size distribution of PM near a bank barrier reef off the West Indies Laboratory on St. Croix, U.S.V.I. Size distributions were determined by filtration through selected sieves and filters ranging between 250 and $0.45 \mu$ m. Results showed that PM was greater in back-reef than fore-reef areas and greater during day than night hours. The PM collected on the smallest filters (0.45 $\mu \mathrm{m})$ remained constant during both sampling periods and could potentially supply $60 \%$ of the daily energy requirements for corals. Inclusion of the PM on the next size filter $(8.0 \mu \mathrm{m})$ would more than account for their daily energy requirements. The mean PM abundance found in this study $\left(1.1 \mathrm{mg} \mathrm{l}^{-1}\right)$ is the same as that reported at another Caribbean laboratory in the West Indies.
\end{abstract}

\section{INTRODUCTION}

Even though hermatypic corals have been considered as specialized planktivorous camivores (Yonge, 1940; Goreau et al., 1971), they possess the ability to occupy several trophic levels. The symbiotic association with zooxanthellae places hermatypic corals at a primary producer level, at the level of herbivores if viewed as consumers of the plant products from their symbiont zooxanthellae (Muscatine and Cernichiari 1969; Lewis and Smith, 1971), or at the level of secondary consumers if viewed as consumers of zooplankton (Porter, 1974; Goreau et al., 1971). They also could be viewed as tertiary consumers if competitive exclusion (Lang, 1973) and feeding upon other carnivorous zooplankton is considered. Lastly, hermatypic corals could be viewed as detritivores and/or suspension feeders if recent studies on bacterial feeding (Disalvo, 1971; Sorokin, 1972, 1974, 1978), mesenterial feeding (Goreau et al., 1971), or uptake of dissolved organic matter (Stephens 1967) is considered.

The fact that many coral species feed on zooplankton has been supported by numerous field and laboratory exercises (Muscatine, 1973). In recent years questions have arisen as to what extent zooplankton meet the nutritional requirements of a given coral species. Some investigators have found the density of zooplankton in a given reef area to be so low that energy derived from the zooplankton community could not begin to approximate the nutritional requirements of corals (Johannes et al., 1970). Franzisket $(1969,1970)$ and Johannes (1974) found that coral species which they tested did not require zooplankton for tissue growth. Experimental individuals held in $1.0-\mu \mathrm{m}$ filtered seawater grew as well as, or better than, controls in unfiltered seawater. Porter (1976) proposed that the ability to capture zooplankton determines the coral's morphology. However, based upon his own studies using the large polyped coral Monastrea cavernosa, only $10 \%$ (to possibly $20 \%$ ) of the daily energy requirements could be met by zooplankton feeding alone.

The role of zooxanthellae in coral nutrition is very controversial (Muscatine, 1973). Even though translocation of organic material from algae to corals is known to occur, its quantitative significance is unknown (Goreau et al., 1971). The only other major source of nutrition is the complex of particulate matter (PM) which exists in all marine ecosystems.

Researchers noted the magnitude of dissolved and particulate organic matter in the sea almost two decades ago (Wangersky, 1959; Riley, 1963; for recent reviews consult 'Marine Ecology', Vol IV: Wangersky, 1978; Conover, 1978; Sorokin, 1978). Even though Goreau et al. (1971) stated how little was known concerning the importance of suspended particulate matter as possible food sources for corals, it was also 
Goreau (1959) who first proposed that evidence supported the view that reef corals are primarily filterfeeders (probably a better term is 'suspension-feeders' (Muscatine, 1973) since the corals do not actually force water through a filter with specific pore sizes). Numerous studies have validated that cilia on coral tentacles not only bring particles to the mouth, but also may serve to reject particles (Muscatine, 1973). More recently Lewis (1977) showed that several coral species captured and ingested particulate matter on mucus strands secreted by coral polyps. Moreover, the particulate matter ingested was adequate to account for the coral's daily energy requirements.

While coral polyps are no doubt opportunistic or facultative predators', it appears that the wide range of suspended particulate matter available to them is also very important. Perhaps the co-existence of many species of corals in a small area is related to their ability to partition the available particulate matter. If corals derive much of their energy from particulate matter and are primarily suspension feeders, then it would be of importance to know the quantity of particulate matter, and prevailing sizes that exist in the vicinity of a coral reef community.

\section{METHODS}

\section{Experimental Design}

Jørgensen (1966) considered that most suspension feeders are able to remove particles less than $1.0 \mu \mathrm{m}$. Franziskett $(1969,1970)$ and Johannes (1974) used 1.0 $\mu \mathrm{r} 2$ filters for filtration in their experiments. The filters selected in the present experiment to fractionate the

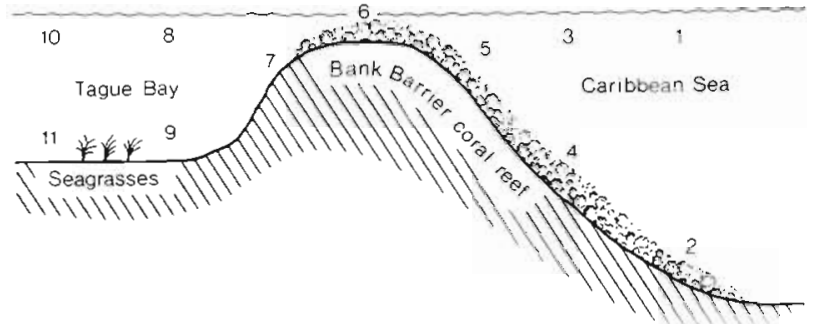

Fig. 2. Location of sample collection sites (numbers) in fore and back reef areas

particulate matter (PM) near a bank barrier reef were $250 \mu \mathrm{m}, 125 \mu \mathrm{r}, 45 \mu \mathrm{m}, 8 \mu \mathrm{m}, 0.8 \mu \mathrm{m}, 0.45 \mu \mathrm{m}$. The site chosen for the study was on a fore and back area of Tague Bay Reef off the West Indies Laboratory on St. Croix, U.S.V.I. (Figs. 1 and 2).

If material is tightly recycled within the coral community, then the quality of such material should be less than in similar non-reef areas. Otherwise, indiscriminate release would allow the material to be carried from the community. Furthermore, if demersal zooplankton play a major role (Porter, 1974) by entering the water column at night then, coupled with the activities of the other animals, the PM should increase during night hours. Lastly, knowing little about the prevailing distribution of size particles, but based upon feeding experiments of other researchers, one would expect the small fraction $(<1.0 \mu \mathrm{m})$ to be sufficiently abundant to provide an adequate nutrition source.

The design allowed for comparisons of PM levels between fore-reef and back-reef areas and between day and night conditions. Differential filtration allowed determinations of different size fractions. The

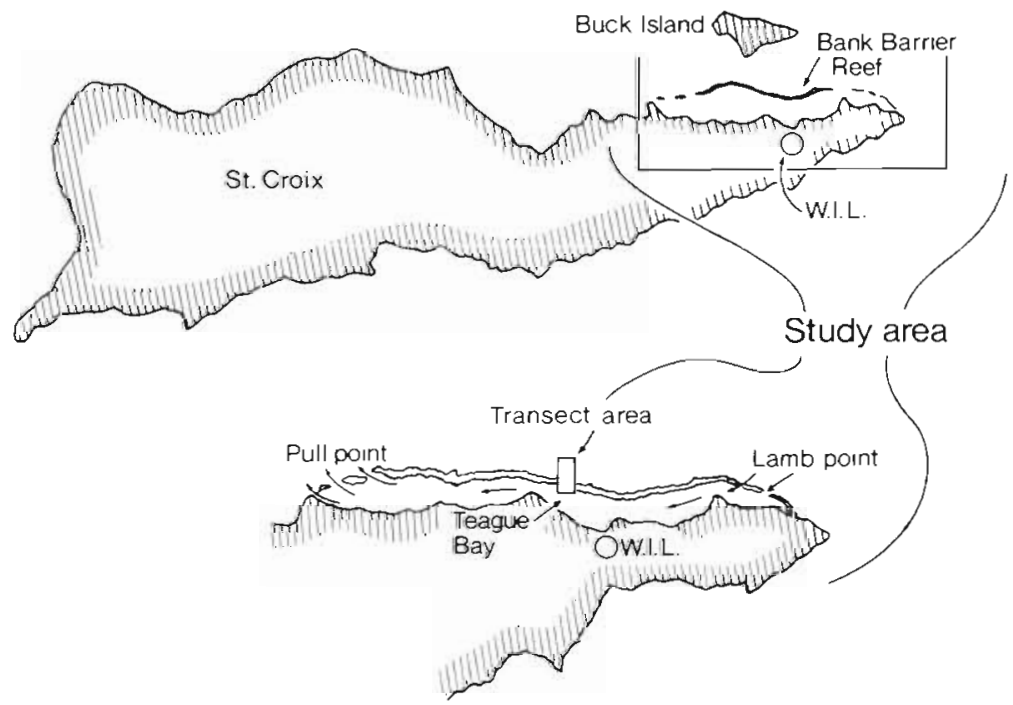

Fig. 1 Location of study area off Tague Bay Reef. W.I.L.: West Indies Laboratory 
three null hypotheses $\left(\mathrm{H}_{0}\right)$ tested were: (1) that the total amount of particulate matter was the same between fore-reef and back-reef areas; (2) the PM was the same between day and night conditions; and (3) the PM concentration was equally distributed among the major size fractions.

\section{Collection of Samples}

Samples to be fractioned were collected with a 5-1 Niskin water bottle. Samples were collected by swimming horizontally at the predetermined level of $0.5 \mathrm{~m}$ and the 'boundary water layer' (Johannes, 1974) among the coral community or near the bottom in noncoral areas. The bottle was manually closed without the introduction of sediment. Water samples were transferred to $4 \mathrm{l}$ (1 gal.) Clorox bottles in the field and returned to the laboratory for processing. Differential filtration (fractionation) was accomplished by passing the water through U.S. Tyler Sieves with mesh openings of $250 \mu \mathrm{l}, 125 \mu \mathrm{m}, 45 \mu \mathrm{m}$. The samples were then passed through Millipore filters with $8.0 \mu \mathrm{n}, 0.8 \mu \mathrm{m}$, and $0.45 \mu \mathrm{m}$ openings. Filtration through the sieves was by gravity. A partial vacuum of $15-17 \mathrm{~cm}$ of $\mathrm{Hg}$ was used to pass the water through the Millipore filters. All $4 \mathrm{l}$ of water sample were filtered or filtration was stopped when the filter reduced passage to 1-5 drops $\min ^{-1}$. All samples were washed with approximately $20 \mathrm{ml}$ of distilled water and placed in aluminium weighing pans. Both pans and filters were desiccated and weighed on a Mettler balance (Model H10T) prior to being used for gravimetric analyses. The samples were then placed in a forced draft drying oven at $80^{\circ} \mathrm{C}$ for $1-2 \mathrm{~h}$, removed, allowed to cool in a desiccator and then reweighed. All samples were kept covered with aluminium foil to reduce contamination by dust. The first series of samples were collected during a day high tide period on July 4, 1977. The second series of samples were collected during a night high tide period on July 7, 1977.

\section{Controls}

A pilot study indicated that differences in weight would not be very great and it would be necessary to account for variability due to processing techniques. Observations indicated that $\mathrm{NaCl}$ and possibly $\mathrm{CaCO}_{3}$ (due to removal of equilibrium carbon dioxide) accumulated on the filters. A series of filters were weighed and $4 \mathrm{l}$ of $0.45 \mu \mathrm{m}$-filtered seawater was processed in exactly the same manner as the experimental samples. The net change in pans and filters due to processing filtered seawater alone are indicated in
Table 1. In tabulating and analyzing raw data, weight, changes due to processing were substracted.

Table 1 Weight gain of PM from filtered seawater

\begin{tabular}{|cccc|}
\hline $\begin{array}{c}\text { Filter/Sieve } \\
(\mu \mathrm{m})\end{array}$ & $\begin{array}{c}\text { Mean } \\
\left(\mathrm{mg} \mathrm{l}^{-1}\right)\end{array}$ & $\begin{array}{c}\text { Standard Dev. } \\
\left(\mathrm{mg}^{-1}\right)\end{array}$ & $\begin{array}{c}\text { Variance } \\
\left(\mathrm{mg} \mathrm{l}^{-1}\right)\end{array}$ \\
\hline 250 & 1.8 & \pm 0.6 & 0.36 \\
125 & 2.0 & \pm 0.2 & 0.03 \\
45 & 1.0 & \pm 0.1 & 0.01 \\
8 & 1.1 & \pm 0.2 & 0.03 \\
0.8 & 0.5 & \pm 0.4 & 0.13 \\
0.45 & 0.6 & \pm 0.2 & 0.04 \\
\hline
\end{tabular}

\section{Current Studies}

Fluorescein dye was used in the surface and bottom areas at the sampling sites to determine patterns of current flow. Several milliliters of the dye were released east of a buoy line and observed for serveral minutes to note direction and speed of water movement.

\section{RESULTS AND DISCUSSION}

\section{Current Studies}

Several dye studies were made to determine the water movement patterns in the vicinity of the study area. In all cases the dye showed the characteristic pattern of 'waves of oscillation', but moved very slowly in a parallel direction to the reef. Direct observations indicated that there was little movement of water across the reef at the study site except by waves of translation. Studies in Tague Bay indicated that the strongest currents, and hence the majority of water, enter Tague Bay at Lamb Point (Fig. 1) and exit at points off Coakley Bay (Routman, 1977).

\section{Particulate Matter Studies}

The PM of the various fractions collected during day and night periods are summarized in Tables 2 and 3 , respectively. A comparison of the fore-reef (Samples 1-5) and back-reef (Samples 7-11) shows that the mean abundance of PM was less in the fore-reef areas. However, using the Mann-Whitney U-test, the difference is not significant at the $10 \%$ level $(P=0.10)$. Therefore, the first hypothesis is rejected and the alternate, the total amount of PM is the same between the two areas, is accepted. However, if only the boundary water' samples are considered between the two areas, then the difference is significant at the $10 \%$ level $(\mathrm{P}=$ $0.10)$. These results are also in agreement with the 
study by Routman (1977) regarding the distribution of particulate organic carbon inside and outside Tague Bay. The increase in PM or POC may be due to the water flowing over the seagrass beds in Tague Bay and accumulating material along the way toward the discharge point(s) off Coakley Bay.

Tables 2 and 3 summarize the differences in concentration between day and night samples. Contrary to expected differences, the night samples (Samples 1-5 and 7-11) were significantly less $(\mathrm{P}=0.10)$ than the day samples (Samples 1-5 and 7-11), and the alternate hypothesis would be accepted. Based upon visual

Table 2. Particulate matter concentrations ( $\mathrm{mg} \mathrm{l}^{-1}$ ) and size distributions near a Caribbean Bank Barrier Reef during a day sampling period

\begin{tabular}{|clllllll|}
\hline $\begin{array}{c}\text { Sample } \\
\text { No. }\end{array}$ & 250 & 125 & 45 & 8 & 0.8 & 0.45 & Total \\
\hline 1 & 0 & 0 & 1.0 & 0.6 & 0.2 & 0 & 1.8 \\
2 & 0 & 0 & 1.4 & 0 & 0 & 0 & 1.4 \\
3 & 0 & 0 & 2.3 & 0 & 0.4 & 0 & 2.7 \\
4 & 0 & 0 & 0.3 & 0 & 0 & 0 & 0.3 \\
5 & 0 & 0.9 & 0.9 & 0.8 & 0.1 & 0 & 2.7 \\
6 & 0 & 0 & 0 & 0 & 0.3 & 0 & 0.3 \\
7 & 0 & 0 & 0 & 1.2 & 0.1 & 3.2 & 4.5 \\
8 & 0 & 0 & 0.2 & 0 & 0 & 0 & 0.2 \\
9 & 0 & 0 & 0 & 0.3 & 0.3 & 1.5 & 2.1 \\
10 & 0 & 0 & 0.3 & 0.7 & 0.5 & 0 & 1.5 \\
11 & 0.3 & 0.5 & 4.1 & 2.5 & 1.1 & 0 & 8.5 \\
mean & 0 & 0.1 & 1.0 & 0.6 & 0.2 & 0.4 & 2.4 \\
\hline
\end{tabular}

Table 3. Particulate matter concentrations ( $\mathrm{mg} \mathrm{l}^{-1}$ ) and size distributions near a Caribbean Bank Barrier Reef during a night sampling period

\begin{tabular}{|clllllll|}
\hline $\begin{array}{c}\text { Sample } \\
\text { No. }\end{array}$ & 250 & 125 & 45 & 8 & 0.8 & 0.45 & Total \\
\hline 1 & 0.6 & 0 & 1.0 & 4.5 & 0 & 0 & 6.1 \\
2 & 0.5 & 0 & 0.4 & 0.4 & 2.4 & 0 & 7.7 \\
3 & 0.5 & 0 & 1.2 & 2.4 & 0.3 & 0 & 4.4 \\
4 & 1.2 & 0.5 & 1.5 & 0.7 & 0.7 & 0.1 & 4.7 \\
5 & 0 & 0 & 0.5 & 0.2 & 0.1 & 0.1 & 0.9 \\
6 & 0 & 0.2 & 1.0 & 0.7 & 0.1 & 0 & 2.0 \\
7 & 0.6 & 0 & 2.1 & 0 & 0.7 & 0.1 & 3.5 \\
8 & 1.3 & 0.2 & 3.3 & 0 & 0.2 & 0.1 & 5.1 \\
9 & 0.7 & 0 & 1.7 & 2.1 & 0.5 & 0.3 & 5.3 \\
10 & 0.1 & 0.7 & 2.8 & 0.7 & 0.7 & 0.3 & 5.3 \\
11 & 0.4 & 0 & 3.3 & 0.9 & 0 & 0.3 & 4.9 \\
mean & 0.5 & 0.1 & 1.7 & 1.1 & 0.5 & 0.1 & 4.5 \\
\hline
\end{tabular}

observations, there were many more zooplankters present during the night sampling periods. However, the Niskin bottle was closed before these organisms were attracted to the diver's lights and the planktonic organisms may have responded by an 'avoidance' of the bottle and divers.

Sorokin $(1973,1978)$ also discussed the mechanism by which wave action and oxygen bubble evolution could cause the movement of organic matter in coral sediments into the water column in the form of bacterial aggregates or detrital particles. Thalassia sp. beds could also contribute PM through much the same process and the contribution should be greater during the day due to higher photosynthetic rates.

Tables 4 and 5 summarize the distribution of the PM between the various size fractions. During the daysampling period the greatest size fraction was between 0.8 and $0.45 \mu \mathrm{m}$. However, during the night-sampling period the total amount of PM found in the smallest

Table 4. Particle distribution (mg $\mathrm{l}^{-1}$ ) during the day sampling period

\begin{tabular}{|cccc|}
\hline $\begin{array}{c}\text { Sample } \\
\text { No. }\end{array}$ & \multicolumn{4}{c|}{ Major size fractions $(\mu \mathrm{m})$} \\
\hline 1 & $250-45$ & 8 & $0.8-0.45$ \\
\hline 2 & 1.6 & 4.5 & 0 \\
3 & 0.9 & 4.4 & 2.4 \\
4 & 1.7 & 2.4 & 0.3 \\
5 & 3.2 & 0.7 & 0.8 \\
6 & 0.5 & 0.2 & 0.2 \\
7 & 1.2 & 0.7 & 0.1 \\
8 & 2.7 & 0 & 0.8 \\
9 & 4.8 & 0 & 0.3 \\
10 & 2.4 & 2.1 & 0.8 \\
11 & 3.6 & 0.7 & 1.0 \\
Mean & 3.7 & 0.9 & 0.3 \\
& 2.4 & 1.5 & 0.6 \\
\hline
\end{tabular}

Table 5. Particle distribution ( $\mathrm{mg} \mathrm{l}^{-1}$ ) during the night sampling period

\begin{tabular}{|cccc|}
\hline $\begin{array}{c}\text { Sample } \\
\text { No. }\end{array}$ & \multicolumn{3}{c}{ Major size fractions $(\mu \mathrm{m})$} \\
& $250-45$ & 8 & $0.8-0.45$ \\
\hline 1 & 1.0 & 0.6 & 0.2 \\
2 & 1.4 & 0 & 0 \\
3 & 2.3 & 0 & 0.4 \\
4 & 0.3 & 0 & 0 \\
5 & 1.8 & 0.8 & 0 \\
6 & 0 & 0 & 0.3 \\
7 & 0 & 1.2 & 3.3 \\
8 & 0.2 & 0 & 0 \\
9 & 0 & 0.3 & 1.8 \\
10 & 0.3 & 0.7 & 0.5 \\
11 & 4.9 & 2.5 & 1.1 \\
Mean & 1.0 & 0.5 & 0.6 \\
\hline
\end{tabular}

range almost equalled that collected between $250-45$ $\mu \mathrm{m}$. It should be noted that the mean PM concentration collected below $1.0 \mu \mathrm{m}$ remained constant whereas, mean PM found between 250-45 $\mu \mathrm{m}$ decreased by $50 \%$. Using the Kruskal-Wallis one-way analysis by ranks, there is a significant difference between particle size during the day and $\mathrm{H}_{0}$ would be rejected. However, at night there was no significant difference at the $10 \%$ level and $\mathrm{H}_{0}$ would be accepted. 
Lewis (1977) summarized information regarding the amount of organic matter necessary to sustain corals. According to him, $0.29 \mathrm{mg}$ dry organic matter $1^{-1}$ is necessary to cover daily maintenance requirements. If according to Wangersky (1965) the organic fraction is approximately $30 \%$ of the total PM fraction, then there is approximately $0.18 \mathrm{mg}$ POC $1^{-1}$ available in the smallest size fraction. This fraction alone could account for approximately $60 \%$ of the daily requirements of hermatypic corals. If the size fraction collected by the $8 \mu \mathrm{m}$ filter is included, then the amount of POC is more than enough to satisfy daily requirements of corals. Most zooplankters exceed this size fraction (8 $\mu \mathrm{m}$ ) and data gathered in this study indicate that, as other investigators have found, there is a sufficient amount of PM available which could supply energy requirements for corals. Lastly, it is important to note that the average concentration of $P M 1^{-1}$ found in the vicinity of Tague Bay Reef at the West Indies Laboratory $\left(1.1 \mathrm{mg}^{-1}\right)$ is the same value reported by Sander (1971) for surface waters off Barbados (1.11 mg dry matter $1^{-1}$ ).

Acknowledgements. Appreciation is extended to Professor Bill Gladfelter for ideas and suggestions regarding this project. Special thanks are due to James Clark, Charles Evans, Art Levitt, Mike Realini, Marc Routman, and Scott Wiecker for helping to collect samples.

\section{LITERATURE CITED}

Conover, R. J. (1978). Transformation of organic matter. In O. Kinne (Ed.), Marine Ecology, Vol. IV, Dynamics. Wiley, Chichester. pp. 221-499.

Disalvo, L. H. (1971). Ingestion and assimilation of bacteria by two scleractinian coral species. In H. M. Lenhoff, L. Muscatine and L. V Davis (Eds), Experimental Coelenterate Biology. University of Hawaii Press, Honolulu. pp. 129-139.

Franziskett, I. (1969). Riffkorallen können autotroph leben. Naturwissenschaften, 56, 144.

Franziskett, I. (1970). The atrophy of hermatypic reef corals maintained in darkness and their subsequent regeneration in light. Int. Revue ges. Hydrobiol., 55, 1-12.

Goreau, T. F. (1959). The ecology of Jamaican coral reefs. I. Species composition and zonation. Ecology, 40,67-90.

Goreau, T. F., Goreau, N. I. and Yonge, C. M. (1971). Reef corals: autotrophy or heterotrophs. Biol. Bull. mar. biol. Lab., Woods Hole, 141, 247-260.

Johannes, R. E. (1974). Sources of nutritional energy for reef corals. In Proceedings of the Second International Coral Reef Symposium. Great Barrier Reef Committee, Brisbane, Australia. pp. 133-137.

Johannes, R. E., Kuenzel, N. T. and Coles, S. L. (1970). The role of zooplankton in the nutrition of some scleractinian corals. Limnol. Oceanogr., 15, 579-586.

Jørgensen, C. B. (1966). Biology of Suspension Feeding, Pergamon Press, London.

Lang, J. (1973). Interspecific aggression by scleractinian corals. 2 . Why the race is not only to the swift. Bull. mar. Sci., 23, 260-279.

Lewis, J. B. (1977). Suspension feeding in Atlantic reef corals and the importance of suspended particulate matter as a food source. In Proceedings of the Third International Coral Reef Symposium. Univ. of Miami, Florida, USA. pp. 406-408.

Lewis, D. H. and Smith, D. C. (1971). The autotrophic nutrition of symbiotic marine coelenterates with special reference to hermatypic corals. I. Movement of photosynthetic products between the symbionts. Proc. $R$. Sac. (Ser B), 178, 111-129.

Muscatine, L. (1973). Nutrition of corals. In O. A. Jones and R. Emdean (Eds), Biology and Geology of Coral Reefs, Vol. 2, Biol. 1. Academic Press, New York. pp. 77-116.

Muscatine, L. and Cernichiari, E. (1969). Assimilation of photosynthetic products of zooxanthellae by a reef coral. Biol. Bull. mar. biol. Lab., Woods Hole, 137, 506-523.

Porter, J. W. (1974). Zooplankton feeding by the Caribbean reef-building coral Montastrea cavernosa. In Proceedings of the Second International Coral Reef Symposium. Great Barrier Reef Committee, Brisbane, Australia. pp. 111-125.

Porter, J. W. (1976). Autotrophy, heterotrophy, and resource partitioning in Caribbean reef-building corals. Am. Nat., $110,731-742$.

Riley, G. A. (1963). Organic aggregates in seawater and the dynamics of their formation and utilization. Limnol. Oceanogr., 8, 372-381.

Routmann, M. (1977). The net productivity of the coral reef ecosystem. Class Report for Ecology and Coral Reefs, West Indies Laboratory, Summer, 1977. (Typed report, unpubl.).

Sander, F. (1971). Organic Productivity of Inshore Water of Barbados. A study of the island mass effects and its causes. Ph. D. Thesis, McGill University.

Sorokin, Y. I. (1972). Bacteria as food of coral reef fauna. Oceanology, 12, 169-177.

Sorokin, Y. I. (1973). Trophical role of bacteria in the ecosystem of the coral reef. Nature, Lond, 242, 415-417.

Sorokin, Y. I. (1974). Bacteria as a component of the coral reef community. In Proceedings of the Second International Coral Reef Symposium. Great Barrier Reef Committee, Brisbane, Australia. pp. 3-10.

Sorokin, Y. I. (1978). Decomposition of organic matter and nutrient regeneration. In $O$. Kinne (Ed.), Marine Ecology, Vol. IV, Dynamics. Wiley, Chichester. pp. 501-616.

Stephens, G. C. (1967). Dissolved organic material as a nutritional source for marine and estuarine invertebrates. In G. H. Lauff (Ed.), Estuaries. Am. Ass. Adv. Sci., Washington. pp. 367-373.

Wangersky, P. J. (1959). Dissolved carbohydrates in Long Island Sound, 1956-1958. Bull. Bingham oceanogr. Coll., 17, 87-94.

Wangersky, P. J. (1965). The organic chemistry of seawater. Am. Scient., 53, 358-374.

Wangersky, P. J. (1978). Production of dissolved organic matter. In O. Kinne (Ed.), Marine Ecology, Vol. IV, Dynamics. Wiley, Chichester. pp. 115-220.

Yonge, C. M. (1940). The biology of reef building corals. Scient. Rep. Gt. Bartier Reef Exped., 1, 353-391. 